\title{
Biological and management design for sustainable wetland rice farming in Siak District, Riau, Indonesia
}

\author{
RACHMIWATI YUSUF ${ }^{1}$, INDRA FUADI ${ }^{2}$, USMAN M. TANG ${ }^{3}$, RAHMAN KARNILA ${ }^{3}$, USMAN PATO ${ }^{4, v}$ \\ ${ }^{1}$ Assessment Institute for Agricultural Technology of Riau. Jl. Kaharuddin Nasution Km. 10 No. 341, Pekanbaru 28284, Riau, Indonesia \\ ${ }^{2}$ Food Crops and Horticultural Protection Agency of Riau. Jl. Hangtuah Ujung, Sail, Pekanbaru 28131, Riau, Indonesia \\ ${ }^{3}$ Environmental Sciences Program, Universitas Riau. Jl. H.R. Soebrantas Km. 12.5, Simpang Baru, Panam, Pekanbaru 28293, Riau, Indonesia \\ ${ }^{4}$ Faculty of Agriculture, Universitas Riau. Jl. H.R. Soebrantas Km. 12.5, Simpang Baru, Panam, Pekanbaru 28293, Riau, Indonesia. \\ Tel.: +62-761-63270, Fax.: +62-761-63271, ‘email: usmanpato@yahoo.com
}

Manuscript received: 14 March 2021. Revision accepted: 24 April 2021.

\begin{abstract}
Yusuf RA, Tank UM, Karnila R, Pato U. 2021. Biological and management design for sustainable wetland rice farming in Siak District, Riau, Indonesia. Biodiversitas 22: 2803-2814. This study aimed to develop a management design for sustainable wetland rice farming to promote food security in Siak District, Riau Province. This study was conducted through survey research wherein primary and secondary data were used. In the sustainability analysis, the Rapfish method was used which is based on eight attributes that are a combination of key factors in the sustainability analysis and stakeholder needs analysis. Results showed that the management design that can be implemented to improve the sustainability of rice farming involves preventing the continuous paddy field conversion and thus promote their preservation, improving the farmers' knowledge and skills to create superior human resources, and strengthening agribusiness-based farmer institutions to improve farmers' welfare. The multidimensional sustainability value obtained in three scenarios was within the $50-75 \%$ range, indicating a fairly sustainable status. For this reason, it is recommended to apply scenario 1 wherein sustainability can be increased at low costs and within a relatively short time.
\end{abstract}

Keywords: Food security, lowland rice, management design, sustainable

\section{INTRODUCTION}

Food is a basic human need; therefore, the adequacy of food for everyone at all times is a human right that must be fulfilled (Renstra, Kementan 2015-2019). Food is derived from the products of agriculture, forestry, fisheries, and livestock production, and it may be obtained from terrestrial and aquatic environments; moreover, it may be treated or not and is intended to be taken as food or drink by humans.

Being a sovereign country, Indonesia is committed to realizing food independence. This commitment is stipulated in the Republic of Indonesia Law Number 18 the Year 2012 on Food and Nutrition and then in Republic of Indonesia Government Regulation Number 17 the Year 2015 on Food Security and Nutrition which mandates the government, together with the community, to ensure food independence for all people. Food security is the ability of the state and of the nation to produce diverse food from within the country, sufficiently fulfilling the food needs of all individuals by utilizing the potential of resources, namely, natural, human, social, economic, and local wisdom, with dignity and sustainably.

The term sustainable is now widely used in agricultural programs. Sustainability has the meaning of maintaining an effort that continues or can remain productive in meeting human needs (Diesendorf 2013). A sustainable agriculture system must subsystems, namely, economy, technology, ecology, and society (Dilling 2011; Liu and Zhang 2013; Thanha and Yapwattanaphun 2015; Erbaugh 2019).

The realization of food self-reliance within the framework of regional autonomy could be achieved if the regional government takes into account the various potentials and obstacles that exist so that each region could effectively and efficiently facilitate development under its maximum agroecological potential. Based on this consideration, it is important to analyze the management of paddy rice farming at the regional level, especially in the District of Siak. This study aimed to formulate a sustainable management design for wetland rice farming to promote food security in Siak District, Riau Province.

\section{MATERIALS AND METHODS}

\section{Study area}

This research has been carried out for seven months, starting from January to July 2018, located in the Siak District, Riau Province, Indonesia (Figure 1), and four subdistricts of paddy production, Bunga Raya, Sabak Auh, Sungai Apit, and Sungai Mandau. 


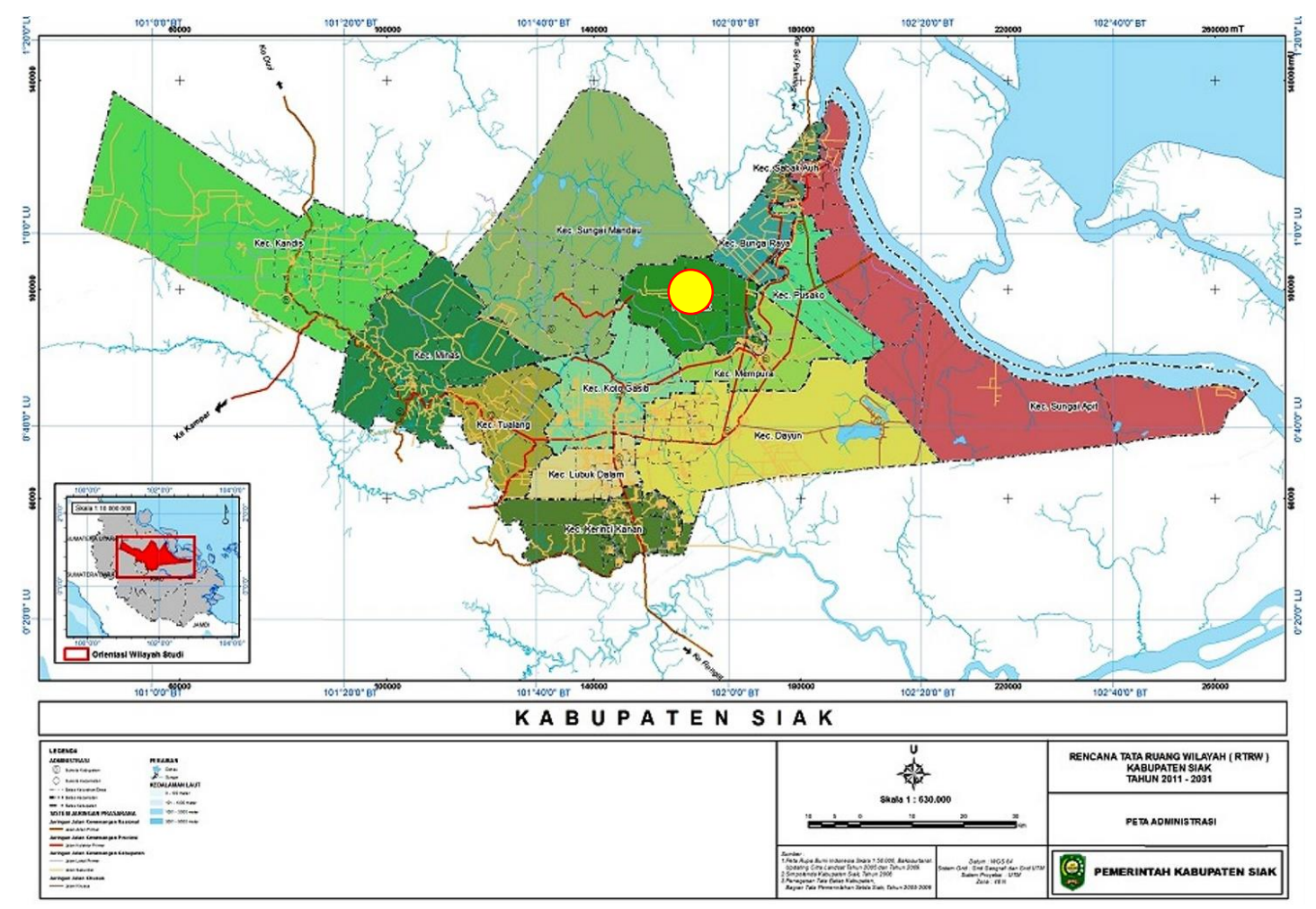

Figure 1. Study area in the Siak District, Riau Province (Sub-District of Bunga Raya, Sabak Auh, Sungai Apit, and Sungai Mandau with yellow spot)

Research on the design of sustainable management of lowland rice farming in Siak District to promote food selfsufficiency was conducted in 2018 in four sub-regencies of rice production centers by using survey methods, literature reviews, and interviews. Primary and secondary data were used in this study. The primary data were collected through interview surveys, field observations, and measurements. The secondary data were collected from various sources, such as research reports, scientific research journals, proceedings, and reports from research institutes, universities, and related agencies. The number of samples was determined using the Slovin equation as reported by Ryan (2013).

$$
\begin{aligned}
& n=\frac{\mathrm{N}}{1+\mathrm{N} * \alpha^{2}} \\
& \text { Where: } \\
& n \quad: \text { number of samples } \\
& \mathrm{N} \quad: \text { total population } \\
& \alpha \quad \text { : percentage of error }
\end{aligned}
$$

The proportion of respondents from farm households for each sub-district was calculated using the minimal number of respondents approach as modified from Darmawan (2015).

$$
P_{m}=\frac{N}{N_{t}} \times n
$$

Where:

$P_{m}$ : proportion of the minimum number of respondents

$N$ : number of standard paddy fields in each village
$N_{t} \quad$ : total number of paddy fields

$n \quad$ : total number of respondents

This research involved the following stages: (a) a literature study wherein findings on rice farming and the factors that influence it were collected; (b) determination of the main attributes of the ecological, economic, sociocultural, technological, and institutional aspects that affect the sustainable management of paddy rice farming; (c) field survey; (d) data analysis; (e) development of alternative scenarios for managing wetland rice farming based on the analysis results in the previous stage and (f) compilation of the sustainable management designs for lowland rice farming. Sustainability analysis was carried out using the multi-dimensional scaling (MDS) analysis approach based on the modified Rapfish program, the key factor in determining sustainability status was obtained through prospective analysis (Pitcher et al. 2013).

\section{RESULTS AND DISCUSSION}

\section{Scenarios for the sustainable paddy farming in Siak District}

The possible future scenarios were established based on the results for the key sustainability factors, along with the needs of the stakeholders. The state of each key factor in each district is presented in Table 1. 
Table 1. Changes in the state of the key factors in the management of sustainable lowland rice farming in Siak District

\begin{tabular}{|c|c|c|c|c|}
\hline \multirow{2}{*}{$\begin{array}{l}\text { Sub-district/ } \\
\text { Key factors }\end{array}$} & \multirow{2}{*}{ Existing condition } & \multicolumn{3}{|c|}{ Future conditions } \\
\hline & & Scenario 1 & Scenario 2 & Scenario 3 \\
\hline \multicolumn{5}{|l|}{ Bunga Raya } \\
\hline Land conversion & $1 \mathrm{~A}$ & $1 \mathrm{~B}$ & $1 \mathrm{C}$ & 1D \\
\hline \multirow[t]{2}{*}{ rate } & 2 & 2 & 2 & 2 \\
\hline & Low & low & Low & Low \\
\hline \multirow{2}{*}{$\begin{array}{l}\text { Use of chemical } \\
\text { pesticides }\end{array}$} & $2 \mathrm{~A}$ & $2 \mathrm{~B}$ & $2 \mathrm{C}$ & 2D \\
\hline & $\begin{array}{l}0 \\
\text { above the } \\
\text { recommended level }\end{array}$ & $\begin{array}{l}1 \\
\text { below the } \\
\text { recommended level }\end{array}$ & $\begin{array}{l}1 \\
\text { below the recommended } \\
\text { level }\end{array}$ & $\begin{array}{l}2 \\
\text { within the recommended level }\end{array}$ \\
\hline Availability of & $3 \mathrm{~A}$ & $3 \mathrm{~B}$ & $3 \mathrm{C}$ & $4 \mathrm{D}$ \\
\hline \multirow{2}{*}{ farmers' capital } & 1 & 2 & 2 & 3 \\
\hline & lack of capital & sufficient capital & sufficient capital & no capital-related problems \\
\hline \multirow{3}{*}{$\begin{array}{l}\text { Potential of } \\
\text { agrotourism }\end{array}$} & & 4B & $4 \mathrm{C}$ & $4 \mathrm{D}$ \\
\hline & & 2 & 2 & 3 \\
\hline & $\begin{array}{l}\text { available } \& \text { started as } \\
\text { well managed }\end{array}$ & $\begin{array}{l}\text { available } \& \text { started as } \\
\text { well managed }\end{array}$ & $\begin{array}{l}\text { available \& started as well } \\
\text { managed }\end{array}$ & $\begin{array}{l}\text { available \& started as well } \\
\text { managed }\end{array}$ \\
\hline & $5 \mathrm{~A}$ & $5 \mathrm{~B}$ & $5 \mathrm{C}$ & $5 \mathrm{D}$ \\
\hline \multirow{2}{*}{ training/counseling } & & 3 & 4 & 4 \\
\hline & twice/year & three times/year & four times/year & four times/year \\
\hline \multicolumn{5}{|l|}{ Sabak Auh } \\
\hline \multirow{3}{*}{$\begin{array}{l}\text { Average land area } \\
\text { ownership }\end{array}$} & $1 \mathrm{~A}$ & $1 \mathrm{~B}$ & $1 \mathrm{C}$ & 1D \\
\hline & 1 & 2 & 3 & 4 \\
\hline & $>0.5-1$ ha & $>1.0-1.5 \mathrm{ha}$ & $>1.5-2$ ha & $>2$ ha \\
\hline \multirow{3}{*}{$\begin{array}{l}\text { Land conversion } \\
\text { rate }\end{array}$} & $2 \mathrm{~A}$ & $2 \mathrm{~B}$ & $2 \mathrm{C}$ & 2D \\
\hline & 2 & 2 & 2 & 2 \\
\hline & Low & Low & Low & Low \\
\hline \multirow{3}{*}{$\begin{array}{l}\text { Participation in } \\
\text { training/counseling }\end{array}$} & $3 \mathrm{~A}$ & $3 \mathrm{~B}$ & $3 \mathrm{C}$ & $3 \mathrm{D}$ \\
\hline & 1 & 2 & 3 & 4 \\
\hline & once/year & twice/year & three times/year & four times/year \\
\hline \multirow[t]{3}{*}{ Farming traditions } & & $4 \mathrm{~B}$ & $4 \mathrm{C}$ & 4D \\
\hline & 0 & 1 & 2 & 2 \\
\hline & none & $\begin{array}{l}\text { available but not } \\
\text { optimal }\end{array}$ & $\begin{array}{l}\text { available and running } \\
\text { optimally }\end{array}$ & $\begin{array}{l}\text { available and running } \\
\text { optimally }\end{array}$ \\
\hline Existence of the & $5 \mathrm{~A}$ & $5 \mathrm{~B}$ & $5 \mathrm{C}$ & $5 \mathrm{D}$ \\
\hline Agency for Logistic & 0 & 0 & 1 & 2 \\
\hline Affairs & None & none & available but insufficient & available and sufficient \\
\hline Sungai Apit & & & & \\
\hline Average land area & $1 \mathrm{~A}$ & 1B & $1 \mathrm{C}$ & 1D \\
\hline ownership & 0 & 1 & 2 & 3 \\
\hline & $<0.5$ & $0.5-1$ ha & $>1-1.5$ ha & $>1.5-2 \mathrm{ha}$ \\
\hline Land conversion & $2 \mathrm{~A}$ & $2 \mathrm{~B}$ & $2 \mathrm{C}$ & $2 \mathrm{D}$ \\
\hline rate & 2 & 2 & 2 & 2 \\
\hline & Low & Low & Low & Low \\
\hline Participation in & $3 \mathrm{~A}$ & $3 \mathrm{~B}$ & $3 \mathrm{C}$ & 3D \\
\hline training/counseling & 1 & 2 & 3 & 4 \\
\hline & once/year & once/year & three times/year & four times/year \\
\hline Farming traditions & $4 \mathrm{~A}$ & 4B & $4 \mathrm{C}$ & 4D \\
\hline & 0 & 1 & 2 & 2 \\
\hline & none & $\begin{array}{l}\text { available but not } \\
\text { optimal }\end{array}$ & $\begin{array}{l}\text { available and running } \\
\text { optimally }\end{array}$ & $\begin{array}{l}\text { available and running } \\
\text { optimally }\end{array}$ \\
\hline Existence of the & $5 \mathrm{~A}$ & $5 \mathrm{~B}$ & $5 \mathrm{C}$ & $5 \mathrm{D}$ \\
\hline Agency for Logistic & 0 & 0 & 1 & 2 \\
\hline Affairs & None & None & available but insufficient & available and sufficient \\
\hline Sungai Mandau & & & & \\
\hline Average land area & $1 \mathrm{~A}$ & $1 \mathrm{~B}$ & $1 \mathrm{C}$ & 1D \\
\hline ownership & 1 & 2 & 3 & 4 \\
\hline & $>0.5-1$ ha & $>1.0-1.5 \mathrm{ha}$ & $>1.5-2$ ha & $>2$ ha \\
\hline Land conversion & $2 \mathrm{~A}$ & $2 \mathrm{~B}$ & $2 \mathrm{C}$ & $2 \mathrm{D}$ \\
\hline rate & 2 & 2 & 2 & 2 \\
\hline & Low & low & Low & Low \\
\hline Participation in & $3 \mathrm{~A}$ & $3 \mathrm{~B}$ & $3 \mathrm{C}$ & $3 \mathrm{D}$ \\
\hline training/counseling & 1 & 2 & 3 & 4 \\
\hline & once/year & once/year & three times/year & four times/year \\
\hline Farming traditions & $4 \mathrm{~A}$ & $4 \mathrm{~B}$ & $4 \mathrm{C}$ & 4D \\
\hline & 0 & 1 & 2 & 2 \\
\hline & none & $\begin{array}{l}\text { available but not } \\
\text { optimal }\end{array}$ & $\begin{array}{l}\text { available and running } \\
\text { optimally }\end{array}$ & $\begin{array}{l}\text { available and running } \\
\text { optimally }\end{array}$ \\
\hline Existence of the & $5 \mathrm{~A}$ & $5 \mathrm{~B}$ & $5 \mathrm{C}$ & $5 \mathrm{D}$ \\
\hline Agency for Logistic & 0 & 0 & 1 & 2 \\
\hline Affairs & None & None & available but insufficient & available and sufficient \\
\hline
\end{tabular}


As shown in Table 1, three possible scenarios for the management of sustainable wetland rice farming were established. The formulation of the scenarios was arranged as presented in Table 2. (i) Scenario 1: Pessimistic scenario wherein improvements in the management of lowland rice farming are made by increasing the score of some sensitive attributes on dimensions that are not sustainable even minimally. (ii) Scenario 2: Moderate scenario wherein improvements in the management of lowland rice farming are made by optimally increasing the score of some sensitive attributes. (iii) Scenario 3: Optimistic scenario wherein improvements in the management of lowland rice farming are made by maximally increasing the score of all sensitive attributes.

The scenario development in Table 2 is based on the time availability and capability of the community, the stakeholders, and the government to serve as policymakers in the future.

\section{Scenario 1}

In scenario 1, improvements in the management of lowland rice farming are made as needed so that the time and costs incurred can be reduced to as little as possible. This improvement is achieved by increasing the scores of some sensitive attributes for the unsustainable dimensions, as presented in Table 3. The changes in the scores of several key attributes were subjected to RAP-Rice analysis to measure the increase in the sustainability index of the management of lowland rice farming. The magnitude of changes in the index value based on the results of the RAPRice analysis is presented in Table 4.

Table 4 and Figure 2 show that in scenario 1, all dimensions indicate that the sustainability for all regencies falls within the sufficient category, except for the economic dimension for the sub-district Bunga Raya, which falls within the highly sustainable category. In Bunga Raya, the sustainability in the economic dimension is largely determined by the provision of more supporting facilities and infrastructure, such as the availability of irrigation to guarantee water supply for plant growth, wider land ownership, and availability of agricultural tools and machinery, compared with that in the other sub-regencies. That improved water and good water management systems have a positive effect on increasing crop production (Zaharaddeen et al., 2017; Shafiqullad and Machito, 2017). This statement is in line with Latiri et al. (2010) and Suciantini (2015) that rainfall is highly correlated to the component results, the results of Indah et al., (2015) research that the average productivity of irrigation fields in South Lampung District is 7.28 tons/ha and rice fields rain 4.37 tons/ha. Lailiyah et al. (2017) stated the productivity of rice paddy irrigation in Lea Wai Village, Central Maluku District averaged 5.36 tons/ha while the productivity of rice paddy that depends on rainwater only about 3.85 tons/ha. According to Sanchez et al. (2019) sustainable water management for irrigation is one of the requirements for the sustainability of farming in agriculture.

For wider land ownership Chenchen et al. (2019) stated that the tendency to decrease the area of land ownership will affect the amount of product obtained and impact on the net profit and welfare of farmers so that household income from the agricultural sector to total income is also likely to decrease. Nazam et al. (2011) explained that in West Nusa Tenggara, the minimum land area to meet the needs of farmers' decent living is 0.73 ha/family unit, while Susilowati and Maulana (2012) stated that to earn an income equivalent to or above the Poverty Limit According to the Indonesian Central Bureau of Statistics, farmers must have a minimum land area of 0.65 ha/family unit.

The availability of agricultural tools and machinery today is urgently needed to increase productivity. The role of agricultural tools and machinery is very important because of the demands of crop cultivation technology needs. This is following the statement (Unadi and Suparlan, 2011; Effendi et al. 2014) that to increase agricultural productivity one of them can be done by the development of agricultural mechanization and post-harvest. Amrullah and Sholih (2016) stated that the processing of rice farming land using hand tractor machines can streamline working time, where the biggest cost difference lies in the difference in labor use that reaches $30 \%$ of the total cost of farming by manual means. Gershom et al, 2019 stated that the use of agricultural tools and machinery in the rice intensification system increased production efficiency by $17 \%$ and decreased waste production to $4.8 \%$.

The existing facilities and the pre-agricultural inputs that increase the production and productivity of the paddy fields also increase the farmers' income. Other factors that promote sustainability in the economic dimension in Bunga Raya Sub-district include the availability of farmers' capital, easy marketing of agricultural products with an indication of higher grain prices, and the large contribution of income from rice farming to meet household needs. Jayne et al. (2019) added that the availability of capital, technology, and knowledge of farmers is crucial to the sustainability of agricultural businesses. According to Villanoa et al. (2018), the ease by which farmers could access market information and could promote their products is a success factor in developing a business.

With the implementation of the strategy in scenario 1, the average combined sustainability index of all the regencies increased by 1.72 , that is, from $53.30 \%$ to $55.02 \%$. Although the combined sustainability index has increased, efforts to optimally improve the key attributes must be continued in the future. For this reason, government policy support is urgently needed so that the management of lowland rice farming in Siak District remains sustainable. This finding is in line with the results of Komatsuzaki (2011) and Abdollahzadeh et al. (2015) wherein the sustainability of the agricultural business is not only the responsibility of farmers but also by the government.

\section{Scenario 2}

In scenario 2, efforts were made to improve the management of paddy farming by optimally increasing the score of the key attributes. This approach is based on the consideration that the management of lowland rice farming is carried out in stages while still considering the ability of 
available funds. The key attributes that were improved in the scores are shown in Table 5.

The scores of some of the key attributes in Table 5 were used as a basis in conducting a RAP-Rice analysis to measure the increase in the sustainable management index of lowland rice farming in the Siak District. The magnitude of the changes in the index value based on the results of the RAP-Rice analysis is shown in Table 6.

The increase in sustainability index in scenario 2 is shown by elevated diagrams in Figure 3. Table 6 and Figure 3 show that the combined value for all the dimensions of sustainability in all sub-regencies increased by an average of 4.13 , that is, from $53.30 \%$ to $57.43 \%$.
This increase is greater than that in scenario 1 wherein the increase was only 1.72 (Table 4). This disparity was observed because, in scenario 1, the scores of only a few sensitive attributes were minimally increased. By contrast, the value of sustainability in scenario 2 was increased by optimally increasing the scores of some sensitive attributes, such as the land area that could be owned, the presence of the Agency for Logistic Affairs, the frequency of attending training/counseling, the frequency of chemical pesticide application by following the instructions for use and the recommended application, and the amount of capital.

The increase in sustainability index in scenario 1 is shown by kite diagrams in Figure 2 .

Table 2. Analysis results for the management scenarios for rice farming in Siak District

\begin{tabular}{|c|c|c|c|c|c|c|}
\hline Value & Scenario & \multicolumn{5}{|c|}{ Arrangement of factors } \\
\hline 0 & Existing conditions & $1 \mathrm{~A}$ & $2 \mathrm{~A}$ & $3 \mathrm{~A}$ & $4 \mathrm{~A}$ & $5 \mathrm{~A}$ \\
\hline 1 & Pessimistic (scenario 1) & $1 \mathrm{~A}$ & $2 \mathrm{~B}$ & $3 B$ & $4 \mathrm{~A}$ & $5 B$ \\
\hline 2 & Moderate (scenario 2) & $1 \mathrm{~A}$ & $2 \mathrm{~B}$ & $3 B$ & $4 \mathrm{~A}$ & $5 \mathrm{C}$ \\
\hline 3 & Optimistic (scenario 3) & $1 \mathrm{~A}$ & $2 \mathrm{D}$ & $3 \mathrm{D}$ & $4 \mathrm{D}$ & $5 \mathrm{D}$ \\
\hline
\end{tabular}

Table 3. Changes in the score of the attributes that influence the improvement of the management status of lowland rice farming in Siak District under scenario 1

\begin{tabular}{llcc}
\hline \multicolumn{1}{c}{ Sub-district/Key attributes } & \multicolumn{3}{c}{ Score } \\
\cline { 2 - 3 } & Existing & Scenario & Scale \\
Bunga Raya & & \\
$\quad$ Land conversion rate & 2 & 2 & $0-2$ \\
Use of chemical pesticides & 0 & 1 & $0-2$ \\
Availability of farmer's capital & 1 & 2 & $0-3$ \\
Potential of agrotourism & 2 & 2 & $0-3$ \\
Participation in training/counseling & 2 & 3 & $0-4$ \\
Sabak Auh & & & \\
Average land area owned by farmers & 1 & 2 & $0-4$ \\
Land conversion rate & 2 & 2 & $0-2$ \\
Participation in training/counseling & 1 & 2 & $0-4$ \\
Farming traditions & 0 & 1 & $0-2$ \\
Existence of the Agency for Logistic & 0 & 0 & $0-2$ \\
Affairs & & & \\
Sungai Apit & & & \\
Average land area owned by farmers & 0 & 1 & $0-4$ \\
Land conversion rate & 2 & 2 & $0-2$ \\
Participation in training/counseling & 1 & 2 & $0-4$ \\
Farming traditions & 0 & 1 & $0-2$ \\
Existence of the Agency for Logistic & 0 & 0 & $0-2$ \\
Affairs & & & \\
Sungai Mandau & & & \\
Average land area owned by farmers & 1 & 2 & $0-4$ \\
Land conversion rate & 2 & 2 & $0-2$ \\
Participation in training/counseling & 1 & 2 & $0-4$ \\
Farming traditions & 0 & 1 & $0-2$ \\
Existence of the Agency for Logistic & 0 & 0 & $0-2$ \\
Affairs & & & \\
\hline
\end{tabular}

Table 4. Changes in the sustainability index for managing paddy rice farming in Siak District under scenario 1

\begin{tabular}{|c|c|c|c|}
\hline Dimension & $\begin{array}{l}\text { Index for } \\
\text { the existing } \\
\text { condition }\end{array}$ & $\begin{array}{l}\text { Index for } \\
\text { scenario } 1\end{array}$ & Difference \\
\hline \multicolumn{4}{|l|}{ Bunga Raya } \\
\hline Ecology & 56.10 & 57.50 & 1.40 \\
\hline Economy & 80.10 & 83.40 & 3,30 \\
\hline Socio-cultural aspect & 56.70 & 60.00 & 3,30 \\
\hline Technology & 56.70 & 56.70 & 0.00 \\
\hline Institution & 53.90 & 53.90 & 0.00 \\
\hline All dimensions combined & 60.70 & 62.30 & 1.60 \\
\hline \multicolumn{4}{|l|}{ Sabak Auh } \\
\hline Ecology & 52.80 & 54.60 & 1.80 \\
\hline Economy & 52.90 & 52.90 & 0.00 \\
\hline Socio-cultural aspect & 51.10 & 53.70 & 2.60 \\
\hline Technology & 51.40 & 51.40 & 0.00 \\
\hline Institution & 46.00 & 50.40 & 4.40 \\
\hline All dimensions combined & 50.84 & 52.60 & 1.76 \\
\hline \multicolumn{4}{|l|}{ Sungai Apit } \\
\hline Ecology & 48.80 & 51.00 & 2.20 \\
\hline Economy & 55.70 & 55.70 & 0.00 \\
\hline Socio-cultural aspect & 47.70 & 50.00 & 2.30 \\
\hline Technology & 53.90 & 53.90 & 0.00 \\
\hline Institution & 46.00 & 50.40 & 4.40 \\
\hline All dimensions combined & 50.42 & 52.20 & 1.78 \\
\hline \multicolumn{4}{|l|}{ Sungai Mandau } \\
\hline Ecology & 54.90 & 56.50 & 1.60 \\
\hline Economy & 52.90 & 52.90 & 0.00 \\
\hline Socio-cultural aspect & 51.10 & 53.70 & 2.60 \\
\hline Technology & 51.40 & 51.40 & 0.00 \\
\hline Institution & 46.00 & 50.40 & 4.70 \\
\hline All dimensions combined & 51.26 & 52.98 & 1.78 \\
\hline $\begin{array}{l}\text { All dimensions combined } \\
\text { for all sub-regencies }\end{array}$ & 53.30 & 55.02 & 1.72 \\
\hline
\end{tabular}




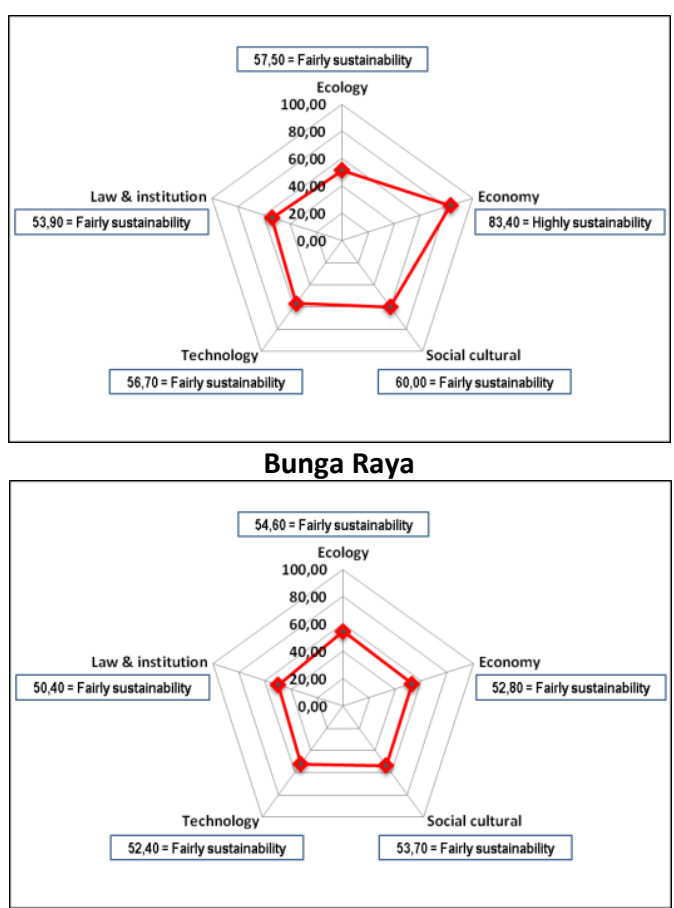

Sabak Auh

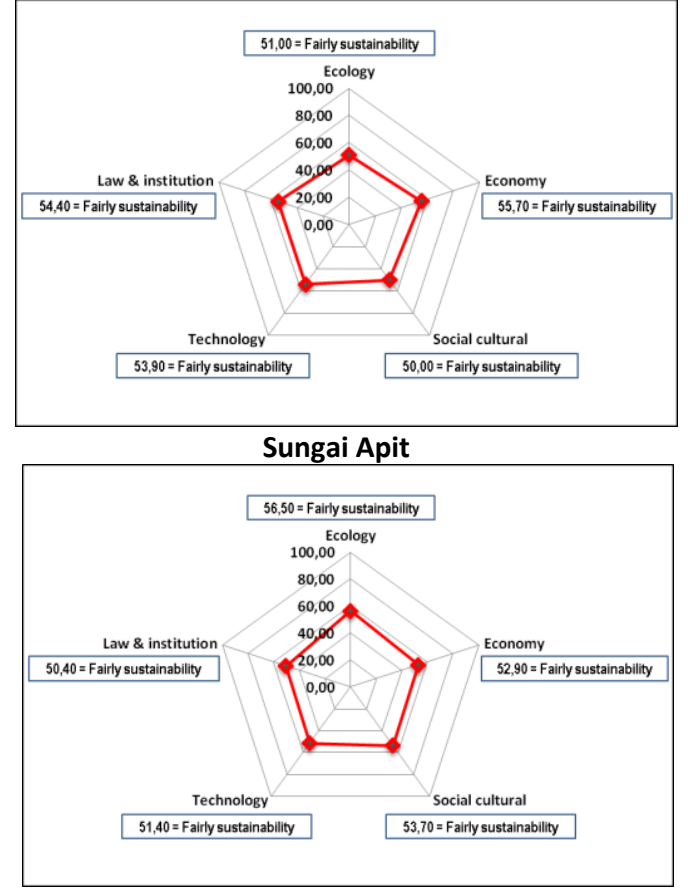

Sungai Mandau

Figure 2. Elevated diagram for the sustainability index for the five sustainability dimensions of paddy farming management in four subregencies in Siak District under scenario 1.

Increasing the scores for all sensitive attributes that are included in the key factors can increase the sustainability index for the management of lowland rice farming in the Siak District. According to (Kamsia et al. 2014; Luo et al. 2014; Uphoff and Frank 2016 and Ademola et al. 2019), the reduced use of chemical fertilizers and pesticides will improve the safety of the food produced, and this result serves as a basis for pursuing sustainable agriculture. Jayne et al. (2019) stated that the availability of capital, technology, and knowledge of farmers is crucial to the sustainability of agricultural businesses. Enggarani (2016) and Villanoa et al. (2018) added that the ease by which farmers could access market information and could promote their products is a success factor in the development of agricultural businesses.

\section{Scenario 3}

Scenario 3 illustrates the maximum improvement efforts made in all key attributes, especially in unsustainable dimensions. This improvement certainly involves a large cost and requires a long time, but it can be achieved with a strong commitment and participation of all parties involved. Some of the key factors that were sought to be improved under scenario 3 are shown in Table 7 .

The results indicating a change in the scores of several key attributes were subjected to a RAP-Rice analysis to measure the increase in the sustainability index of lowland rice farming in the Siak District. The magnitude of changes in the index value based on the results of the RAP-Rice analysis is presented in Table 8 . The increase in the sustainability index for scenario 3 is shown in kite diagrams in Figure 4.

Table 8 and Figure 4 show that a maximum increase in the scores for all sensitive attributes gives better results compared with the minimal and optimal increase in scores that resulted in $52.98 \%$ (Table 4) and $57.43 \%$ (Table 7) increase in sustainability index, respectively. In scenario 3 , the average increase in the combined sustainability index was 6.55 , that is, from $53.30 \%$ to $59.85 \%$.

The level of sustainability in the management of lowland rice farming in the Siak District can be improved by changing the key attributes for the ecological, sociocultural, and institutional dimensions. The application of the three scenarios will result in a certain level of sustainability in each dimension in the management of paddy rice fields in the four sud-district. Moreover, Table 8 shows that the multidimensional sustainability index for all the regencies lies within the $50-75 \%$ range, indicating a fairly sustainable status.

The sustainable management index for lowland rice farming in Siak District can be further increased by handling sensitive attributes, such as increasing the cropping index, facilitating yield marketing, increasing grain prices, and developing, strengthening, and empowering farmer groups, without changing the key factors. This approach is based on the multidimensional sustainability index wherein only $59.85 \%$ was achieved even though optimal improvements in key factors were made; however, it is hoped that the management of these key factors will encourage improvements in other factors so that the index and the sustainability status of the 
management of wetland farming in Siak District as a whole can increase. According to Schnackenberg and Tomlinson (2014), transparency is essential to build trust from members and from stakeholders towards their groups, Villanoa et al. (2018) added good market access and the existence of price policies that do not harm farmers are a success factor in the development of agricultural businesses. Additionally, Lutz et al. (2017) state that good cooperation within farmer groups and the provision of support through adequate facilities, infrastructure, and law enforcement will create a resilient and sustainable local food system. According to David et al. (2019) that to realize the long-term sustainability of agriculture should implement an integrated agricultural system, added to

Table 5. Changes in the scores of the attributes that influence the improvement of the management status of lowland rice farming in Siak District under scenario 2

\begin{tabular}{llcc}
\hline \multicolumn{1}{c}{ Sub-district/Key attributes } & \multicolumn{2}{c}{ Score } \\
\cline { 2 - 3 } & Existing & $\begin{array}{c}\text { Scenario } \\
\text { Scale }\end{array}$ \\
\hline Bunga Raya & 2 & $0-2$ \\
Land conversion rate & 2 & 1 & $0-2$ \\
Use of chemical pesticides & 0 & 3 & $0-3$ \\
Availability of farmer's capital & 1 & 2 & $0-3$ \\
Potential of agrotourism & 2 & 4 & $0-4$ \\
Participation in training/counseling & 2 & & \\
Sabak Auh & & 3 & $0-4$ \\
Average land area owned by farmers & 1 & 2 & $0-2$ \\
Land conversion rate & 2 & 3 & $0-4$ \\
Participation in training/counseling & 1 & 2 & $0-2$ \\
Farming traditions & 0 & 1 & $0-2$ \\
Existence of the Agency for Logistic & 0 & & \\
Affairs & & & \\
Sungai Apit & & 2 & $0-4$ \\
Average land area owned by farmers & 0 & 2 & $0-2$ \\
Land conversion rate & 2 & 3 & $0-4$ \\
Participation in training/counseling & 1 & 2 & $0-2$ \\
Farming traditions & 0 & 1 & $0-2$ \\
Existence of the Agency for Logistic & 0 & & \\
Affairs & & & \\
Sungai Mandau & & 3 & $0-4$ \\
Average land area owned by farmers & 1 & 2 & $0-2$ \\
Land conversion rate & 2 & $0-4$ \\
Participation in training/counseling & 1 & 3 & $0-2$ \\
Farming traditions & 0 & 2 & $0-2$ \\
Existence of the Agency for Logistic & 0 & 1 & \\
Affairs & & & \\
\hline & & & \\
\hline
\end{tabular}

Erbauagh et al, 2019 that what determines the sustainability of farming is the environmental, socio-cultural, and welfare factors of farmers.

\section{Strategy for sustainable paddy farming management}

The strategy for sustainable lowland rice farming management in Siak District is based on eight key attributes or factors derived from a combination of key factors in the sustainability analysis and in the analysis of the needs of stakeholders who exert a dominant influence on sustainability. Based on these eight key attributes or factors, three strategies for managing sustainable rice farming in Siak District are proposed.

Table 6. Changes in the sustainability index for the management of wetland rice farming in Siak District under scenario 2

\begin{tabular}{|c|c|c|c|}
\hline Dimension & $\begin{array}{l}\text { Index for } \\
\text { the existing } \\
\text { condition }\end{array}$ & $\begin{array}{c}\text { Index for } \\
\text { scenario } 2 \\
(\%)\end{array}$ & Difference \\
\hline \multicolumn{4}{|l|}{ Bunga Raya } \\
\hline Ecology & 56.10 & 57,50 & 1.40 \\
\hline Economy & 80.10 & 89.50 & 9.40 \\
\hline Socio-cultural aspect & 56.70 & 64.70 & 8.00 \\
\hline Technology & 56.70 & 56.70 & 0.00 \\
\hline Institution & 53.90 & 53.90 & 0.00 \\
\hline All dimensions combined & 60.70 & 64.46 & 3.76 \\
\hline \multicolumn{4}{|l|}{ Sabak Auh } \\
\hline Ecology & 52.80 & 56.70 & 3.90 \\
\hline Economy & 52.90 & 52.90 & 0.00 \\
\hline Socio-cultural aspect & 51.10 & 56.70 & 5.60 \\
\hline Technology & 51.40 & 51.40 & 0.00 \\
\hline Institution & 46.00 & 58.00 & 12.00 \\
\hline All dimensions combined & 50.84 & 55.14 & 4.30 \\
\hline \multicolumn{4}{|l|}{ Sungai Apit } \\
\hline Ecology & 48.80 & 53.10 & 4.30 \\
\hline Economy & 53.70 & 55.70 & 0.00 \\
\hline Socio-cultural aspect & 47.70 & 52.30 & 4.60 \\
\hline Technology & 53.90 & 53.90 & 0.00 \\
\hline Institution & 46.00 & 58.00 & 12.00 \\
\hline All dimensions combined & 50.42 & 54.60 & 4.18 \\
\hline \multicolumn{4}{|l|}{ Sungai Mandau } \\
\hline Ecology & 54.90 & 58.70 & 3.80 \\
\hline Economy & 52.90 & 52.90 & 0.00 \\
\hline Socio-cultural aspect & 51.10 & 56.70 & 5,60 \\
\hline Technology & 51.40 & 51.40 & 0.00 \\
\hline Institution & 46.00 & 58.00 & 12.00 \\
\hline All dimensions combined & 51.26 & 55.54 & 4.28 \\
\hline $\begin{array}{l}\text { The combined index of all } \\
\text { regencies }\end{array}$ & 53.30 & 57.43 & 4.13 \\
\hline
\end{tabular}



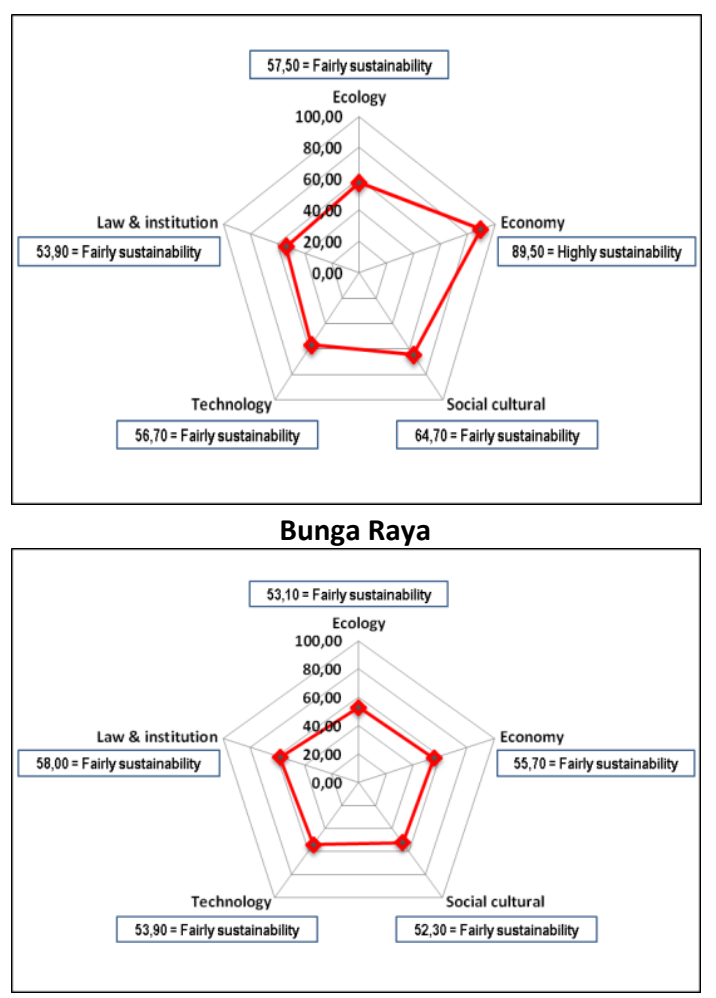

Sabak Auh
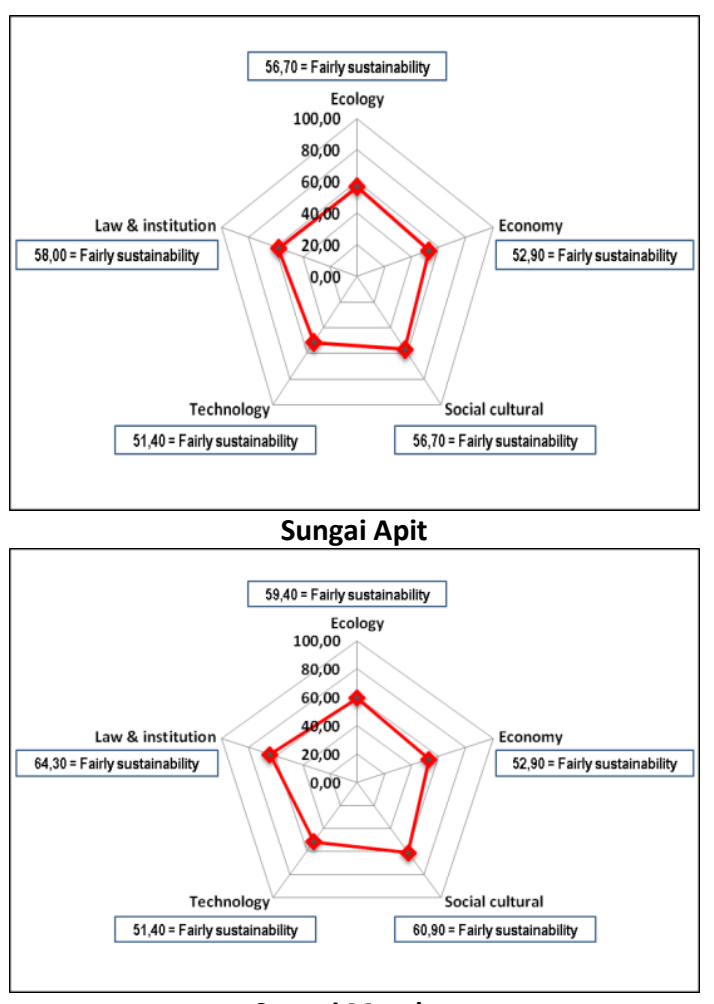

Sungai Mandau

Figure 3. Elevated diagram of the sustainability index for the five dimensions of sustainability for paddy farming management in the four sub-regencies in Siak District under scenario 2.

\section{Strategy 1. Prevent land conversion to maintain sustainable lands for food}

Siak District is a productive area for paddy rice farming; however, its paddy farms are currently being converted into an oil palm plantation despite the considerable importance of large paddy fields in achieving maximum rice production. Moreover, paddy fields are the main target for land conversion for non-agricultural purposes. This land-use change has been carried out in stages by farmers, and it began in 2003. This land conversion will pose a serious threat to food security and sovereignty in the future.

The government has tried to maintain the eternal paddy fields, but implementation on the ground remains difficult. This challenge is due to various factors, such as high competition for land use, especially for regional development, settlements, plantations, and infrastructure. In many cases, the interests for economic development are favored due to the relatively low rents for paddy lands. The interest in pursuing regional own-source revenues (PAD) also often defeats long-term interests in food security.

Pieces of wetland located along highways and close to a town proper are highly vulnerable to conversion. This trend is attributed to the fact that farmers who own these lands feel that they do not hold the responsibility of providing food security services to others. In various meetings, farmers inquired what incentive will the government give so they will maintain their existing paddy fields and forego their opportunity to earn a higher income. Some programs that can be implemented to prevent the conversion of paddy fields are as follows: Allocate agricultural land for sustainable food production that is environmentally sound as characterized by the reduced use of chemical pesticides (i). Exempt taxes related to rice farming (ii). Provide incentives to farmers in the form of subsidized production inputs and set grain prices that are more profitable to farmers (iii). Increase the awareness of farmers and related sectors through socialization, training, and extension to halt land conversion (iv). Increase the understanding of the importance of long-term food security and the strategic position of sustainable agricultural land to all parties, especially the Regent (Bupati) and the House of Representatives (v). Create a program and allocate a budget for infrastructure development, production assistance, and agricultural inputs proportionate to the area of agricultural land used for sustainable food production, which is determined and/or is based on the achievement of the target level of food production (vi). Create a regional regulation on the requirements for the conversion of paddy fields. This regulation should include the provision wherein when the land area to be converted is $>500 \mathrm{~m}^{2}$, a principle of land use permit must be obtained at the One-Stop Integrated Service Office; the land evaluation will involve the Regional Planning Agency, the Agriculture Service, the National Land Agency and the Department of Environment and Forestry. With the implementation of this regional regulation, it is expected that it will be difficult for farmers 
and developers to convert paddy fields into nonagricultural land (vii).

\section{Strategy 2. Increasing farmers' knowledge and skills in applying location-specific technological innovations}

Rice is the backbone of the development of the food crop sub-sector, and it plays an important role in achieving national food security; therefore, the government must be determined to increase rice production and productivity towards sustainable self-sufficiency. One approach to increase rice production sustainably is to increase productivity through the accurate selection of technological components by taking into account the conditions of the biotic and abiotic environments and the optimal land management by farmers who are guided directly by extension agents in the field.

Table 7. Changes in the attribute scores that influence the improvement of the management status of rice farming in Siak District under scenario 3

\begin{tabular}{|c|c|c|c|}
\hline \multirow[b]{2}{*}{ Sub-district/Key attributes } & \multicolumn{2}{|c|}{ Score } & \multirow[b]{2}{*}{ Scale } \\
\hline & Existing & $\begin{array}{c}\text { Scenario } \\
3\end{array}$ & \\
\hline \multicolumn{4}{|l|}{ Bunga Raya } \\
\hline Land conversion rate & 2 & 2 & $0-2$ \\
\hline Use of chemical pesticides & 0 & 2 & $0-2$ \\
\hline Availability of farmer's capital & 1 & 3 & $0-3$ \\
\hline Potential of agrotourism & 2 & 3 & $0-3$ \\
\hline Participation in training/counseling & 2 & 4 & $0-4$ \\
\hline \multicolumn{4}{|l|}{ Sabak Auh } \\
\hline Average land area owned by farmers & 1 & 4 & $0-4$ \\
\hline Land conversion rate & 2 & 2 & $0-2$ \\
\hline Participation in training/counselling & 1 & 4 & $0-4$ \\
\hline Farming traditions & 0 & 2 & $0-2$ \\
\hline $\begin{array}{l}\text { Existence of the Agency for Logistic } \\
\text { Affairs }\end{array}$ & 0 & 2 & $0-2$ \\
\hline \multicolumn{4}{|l|}{ Sungai Apit } \\
\hline Average land area owned by farmers & 0 & 3 & $0-4$ \\
\hline Land conversion rate & 2 & 2 & $0-2$ \\
\hline Participation in training/counselling & 1 & 4 & $0-4$ \\
\hline Farming traditions & 0 & 2 & $0-2$ \\
\hline $\begin{array}{l}\text { Existence of the Agency for Logistic } \\
\text { Affairs }\end{array}$ & 0 & 2 & $0-2$ \\
\hline \multicolumn{4}{|l|}{ Sungai Mandau } \\
\hline Average land area owned by farmers & 1 & 4 & $0-4$ \\
\hline Land conversion rate & 2 & 2 & $0-2$ \\
\hline Participation in training/counselling & 1 & 4 & $0-4$ \\
\hline Farming traditions & 0 & 2 & $0-2$ \\
\hline $\begin{array}{l}\text { Existence of the Agency for Logistic } \\
\text { Affairs }\end{array}$ & 0 & 2 & $0-2$ \\
\hline
\end{tabular}

Appropriate technology component selection will be achieved by increasing farmers' knowledge and skills through training provided by extension agents or by a team of experts. Training and extension materials must be prioritized for the application of site-specific technologies through sustainable integrated crop management approaches, as follows: (i) The use of new varieties with high yields and economic value (ii). The use of highquality and labeled seeds. (iii) Application of organic materials by returning straw or manure into the paddy in the form of compost. (iv) Planting using the legowo row planting system. (v) Balanced fertilization according to plant needs and soil nutrient status. (specific location). (iv) Plant pest control using the integrated pest management approach. (vii) Land management according to seasonal and cropping patterns. (viii) Effective and efficient watering. (ix) Weeding and harvesting on time.

Table 8. Changes in the sustainability index in the management of lowland rice farming in Siak District under scenario 3

\begin{tabular}{|c|c|c|c|}
\hline Dimension & $\begin{array}{l}\text { Index for } \\
\text { the existing } \\
\text { condition }\end{array}$ & $\begin{array}{c}\text { Index for } \\
\text { scenario } 3 \\
(\%)\end{array}$ & Difference \\
\hline \multicolumn{4}{|l|}{ Bunga Raya } \\
\hline Ecology & 56.10 & 61.20 & 5.10 \\
\hline Economy & 80.10 & 95.80 & 15.70 \\
\hline Socio-cultural aspect & 56.70 & 64.70 & 8.00 \\
\hline Technology & 56.70 & 56.70 & 0.00 \\
\hline Institution & 53.90 & 53.90 & 0.00 \\
\hline All dimensions combined & 60.70 & 66.46 & 5.76 \\
\hline \multicolumn{4}{|l|}{ Sabak Auh } \\
\hline Ecology & 52.80 & 59.40 & 6.60 \\
\hline Economy & 52.90 & 52.90 & 0.00 \\
\hline Socio-cultural aspect & 51.10 & 60.90 & 9.80 \\
\hline Technology & 51.40 & 51.40 & 0.00 \\
\hline Institution & 46.00 & 64.30 & 18.30 \\
\hline All dimensions combined & 50.84 & 57.78 & 6.94 \\
\hline \multicolumn{4}{|l|}{ Sungai Apit } \\
\hline Ecology & 48.80 & 55.40 & 6.60 \\
\hline Economy & 55.70 & 55.70 & 0.00 \\
\hline Socio-cultural aspect & 47.70 & 55.30 & 7.60 \\
\hline Technology & 53.90 & 53.90 & 0.00 \\
\hline Institution & 46.00 & 64.30 & 18.30 \\
\hline All dimensions combined & 50.42 & 56.92 & 6.50 \\
\hline \multicolumn{4}{|l|}{ Sungai Mandau } \\
\hline Ecology & 54.90 & 61.70 & 6.80 \\
\hline Economy & 52.90 & 52.90 & 0.00 \\
\hline Socio-cultural aspect & 51.10 & 61,00 & 9.90 \\
\hline Technology & 51.40 & 51.40 & 0.00 \\
\hline Institution & 46.00 & 64.30 & 18.30 \\
\hline All dimensions combined & 51.26 & 58.26 & 7.00 \\
\hline $\begin{array}{l}\text { The combined index of all } \\
\text { the regencies }\end{array}$ & 53.30 & 59.85 & 6.55 \\
\hline
\end{tabular}




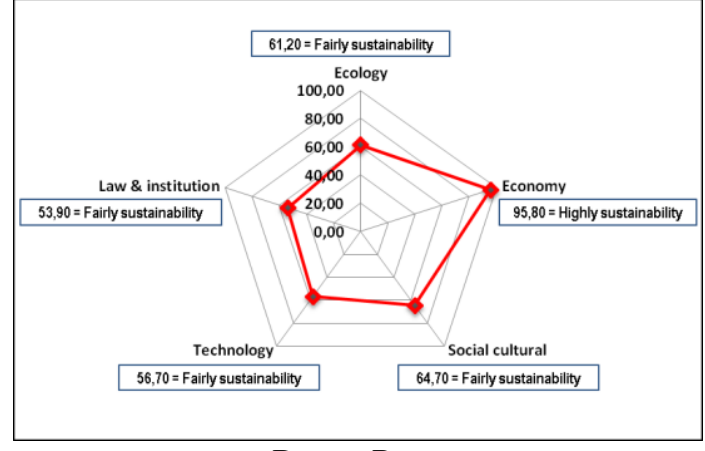

Bunga Raya

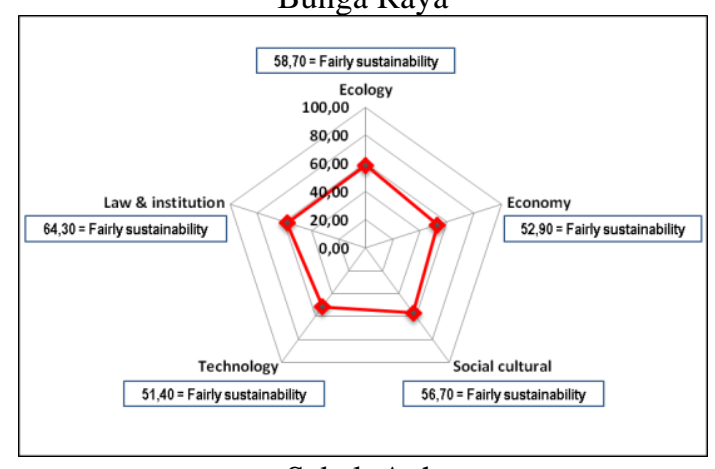

Sabak Auh

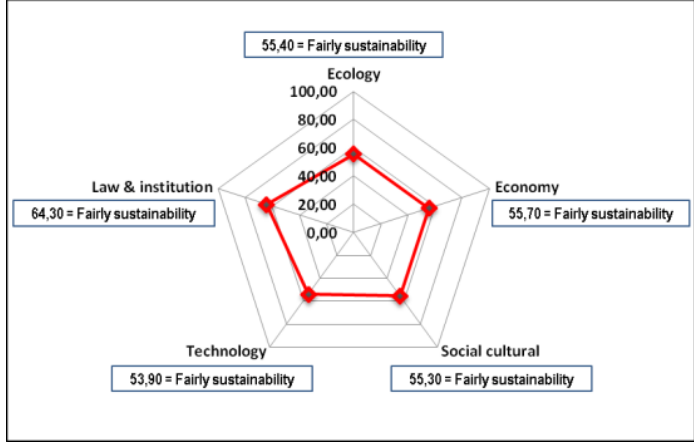

Sungai Apit

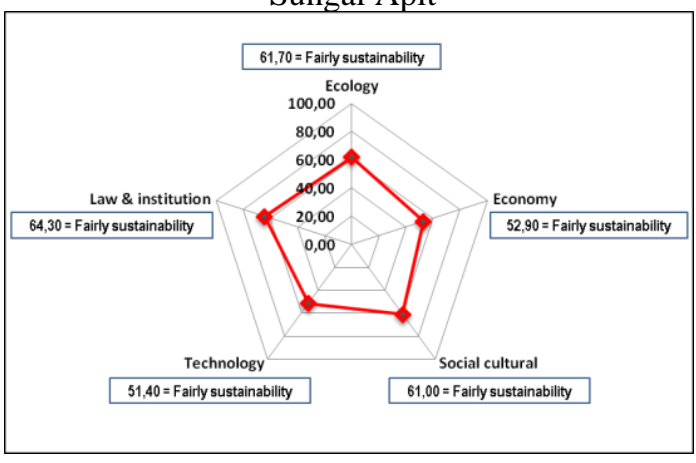

Sungai Mandau

Figure 4. Elevated diagram of the sustainability index value of the five dimensions of sustainability of paddy farming management in scenario 3 in four regencies in Siak District

Increasing the knowledge of farmers through frequent counseling that involves various methods of education, such as open-field, field school, and monthly meetings, are supported by the provision of media outreach in the form of demonstration plots, booklets, leaflets, posters, and magazines. Given that innovation adoption can proceed rather quickly, the presentation of innovations should be simpler. Future programs that can be applied include the following: (i) Assistance and development of environmentally friendly agriculture. (ii) Development of food cropping patterns to promote the increase in cropping index. (iii) Development of organic rice plants to reduce the use of chemical pesticides. (iv) Special efforts to achieve rice self-sufficiency.

These programs are expected to motivate and change the behavior of farmers, that is, they will become more environmentally friendly when cultivating their lowland rice paddies, which in turn will ensure the sustainability of their farms. The formulation of the strategy and the implementation of these programs was carried out under the coordination of the Siak District Agriculture Office by involving the Agricultural Technology Assessment Center, the Plant Protection Center, universities, agricultural entrepreneurs, farmer groups, and other relevant parties, including the people of Siak District.

\section{Strategy 3. Development, empowerment, and institutional strengthening of farmers}

The Farmer Institution has a strategic point in agribusiness management of lowland rice farming.
Currently, farmers in Siak District remain inactively engaged in post-harvest implementation and marketing due to the following: (i) Lack of farmers' insights and knowledge on production management and marketing network issues. (ii) Farmers are not yet fully involved in agribusiness activities; farmer activities are still focused on production activities. (iii) The role and function of farmer institutions as an overseer for farmer organizations are not effectively carried out.

To overcome the problems faced by farmers, it is necessary to develop, empower and strengthen farmers' institutions (including farmer groups, labor institutions, input providers, output institutions, extension agents, and capital institutions) because individual farms operating on their own are disadvantaged. Individual farmers will manage farming businesses by cultivating small and scattered areas and with low capital ownership. The government as a policymaker must strengthen institutions through farmer groups that are stronger both in terms of their being an organization and in terms of capital.

The farmers must be aware that their community or organization was established based on need and not due to coercion and that they are encouraged to embark on certain projects. The efforts or strategic steps in developing farmer institutions that can be taken by stakeholders, especially the government, are as follows: 


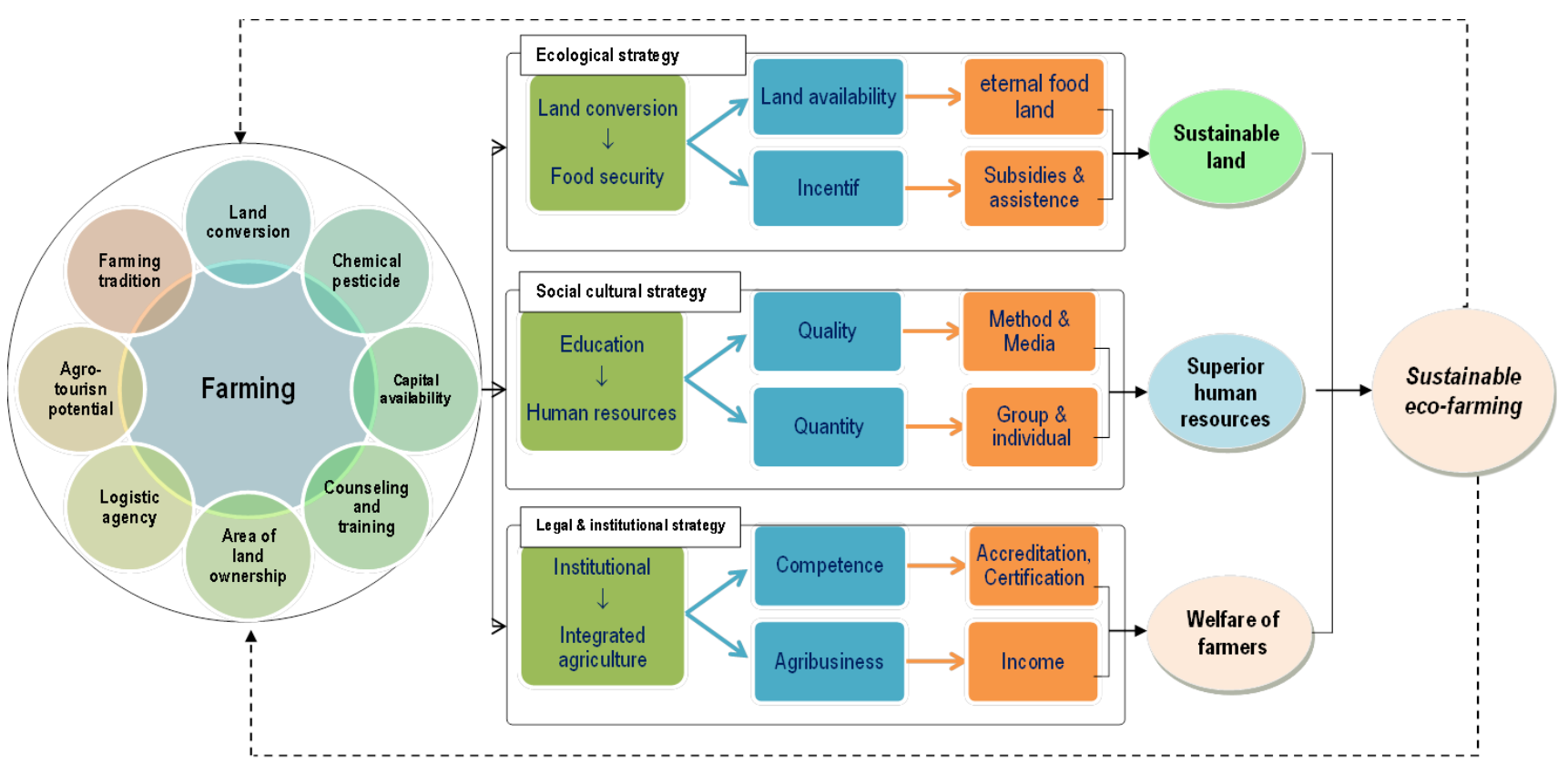

Figure 5. Management design for sustainable wetland rice farming in Siak District, Riau, Indonesia

Increasing agricultural extension support.

Improving the competencies of extension workers in educating farmers; these competencies include their mastery of the material, their communication skills, their attitudes towards a target, and their commitment to the profession. Another is the use of an appropriate extension approach under the characteristics of the target audience, including the appropriateness of the information, the accuracy of the method employed, the use of various counseling techniques, and the use of media in extension services. Strengthening the agricultural extension institutions by ensuring the availability of extension programs, easy access to these programs, and the availability of the needed support facilities.

\section{Building farmers' capacity through}

Provision of improved education, both formal and nonformal. Facilitation of various training activities. Building the farmers' ability to increase their income. Provision of facilities for agribusiness activities for farmers. Provision of learning resources, including information needed by farmers.

\section{Increasing farmers' participation in farmer institutions}

Members' participation in institutions is interpreted as the active choice of the community members to play a role in self-actualization to improve their quality of life.

The development, empowerment, and strengthening of farmer institutions must be promoted through coaching by related agencies (i.e., Riau Provincial Agriculture Office, Siak District Agriculture Office, Riau Assessment Institute for Agricultural Technology, Universities, Cooperatives and Small Business Offices and State-Owned Enterprises and private parties). The management design for lowland rice farming in Siak District is presented in Figure 5.
In conclusion, the management design that can be implemented to improve the sustainability of wetland rice farming to promote food independence in Siak District involves preventing the continuous paddy land conservation, increasing farmers' knowledge and skills to create superior human resources, and strengthening agribusiness-based farmer institutions to improve farmers' welfare. The sustainability of lowland rice farming in the Siak District can be improved by improving the ecological, socio-cultural, and institutional dimensions. Based on multidimensional sustainability, the values obtained in scenarios 1,2 , and 3 are still within the $50-75 \%$ range (quite sustainable). For this reason, scenario 1 is recommended because sustainability can be increased at low costs and within a relatively short time.

\section{REFERENCES}

Abdollahzadeh G, Sharifzadeh MS, Damalas CA. 2015. Perceptions of the beneficial and harmful effects of pesticides among Iranian rice farmers influence the adoption of biological control. Crop Protection. 75: 124-131. DOI: 10.1016/j.cropro.2015.05.018.

Ademola AA, Karin W, Hossein A. 2019. Sustainable agriculture and food security in Africa: the role of innovative technologies and international organizations. Technol Soc 58.101143. DOI: 10.1016/ j.techsoc.2019.05.007.

Amrullah ER, Sholih NH. 2016. The role and contribution of hand tractors to the efficiency of farming in Banten. Proceedings of the National Seminar on Agricultural Technology Innovation, Banjarbaru. July 20, 2016. [Indonesian]

Budi D, Yusni IS, Sukendi S, Siti Z. 2016. Sustainable management of peat swamp forest ecosystems toward forest and land fires in Kampar Peninsula, Sumatera. Human Environ J 23 (2) 195-205. DOI: 10.22146/jml.18791.

Chenchen R, Shen L, Hansvan G, Stefan R, Shuqin J, Hongbin L, Baojing G. 2019. The impact of farm size on agricultural sustainability. J Cleaner Prod 220: 357-367. DOI: 10.1016/j.jclepro. 2019.02.151

Diesendorf M. 2000. Sustainability and sustainable development. In: Dunphy D, Benveniste J, Griffiths A, Sutton P (eds). Sustainability: 
The Corporate Challenge of the 21st Century, Chap. 2: 19-37. Allen \& Unwin, Sydney, NSW.

Dilling PF. 2011. Stakeholder Perception of Corporate Social Responsibility. Intl J Manag Market Res 2 (4): 23-34.

Effendi DS, Zainal A, Bambang P. 2014. Acceleration of swamp land development based on innovation. Pengembangan Inovasi Pertanian 7 (4): 177-186. [Indonesian]

Enggarani NS. 2016. Quality of Public Services in Licensing in Integrated Services One Door, Office of the Investment Agency and Integrated Licensing Services, Boyolali District. J Law Justice 1 (1): 16-29. [Indonesian]

Erbaugh JR, Bierbaum G, Castilleja GAB. da Fonseca, S. Cole, B. Hansen. 2019. Toward sustainable agriculture in the tropics. World Dev 121: 158-162. DOI: 10.1016/j.worlddev. 2019.05.002.

Gershom EM, Mariko K, Aseres ME, John P, Essiagnon A, Xu T. 2019. Recuperating dynamism in agriculture through adoption of sustainable agricultural technology - Implications for cleaner production. J Cleaner Prod 232: 639-647. DOI: 10.1016/j.jclepro. 2019.05.366.

Indah MSL, Wan AZ, Fembriarti EP. 2015. Analysis of production efficiency and revenue of rice paddy farming on technical irrigation land and rainwater land in South Lampung District. J Agribusiness Sci 3 (3): 228-234. [Indonesian]

Jayne TS, Sieglinda S, Frank P, Nicholas S. 2019. Sustainable agricultural intensification in an era of rural transformation in Africa. J Global Food Secur 20: 105-11. DOI: 10.1016/j.gfs. 2019.01.008.

Kamsia B, Shahida MS, Celestina A, Suriani H, Norlita I, Khadizah G 2014. Knowledge, attitude, and practice of pesticide use among oil palm smallholders in Sandakan, Sabah. IOSR J Agric Vet Sci (IOSRJAVS) 7 (11): 18-20.

Komatsuzaki M. 2011. Agro-ecological approach for developing a sustainable farming and food system. J Dev Sustain Agric 6 (1): 54 63. DOI: $10.11178 / j \mathrm{jsa} .6 .54$

Lailiyah N, Natelda RT, Raihana K. 2017. Analysis of rainfed lowland rice (Oryza sativa L) in Lea Wai Village, Subdistrict of North Seram. Agrilan: Jurnal Agribisnis Kepulauan 5 (2): 151-165. [Indonesian]

Latiri K, Lhomme JP, Annabi M, Setter TL. 2010. Wheat production in Tunisia: Progress, inter-annual variability and relation to rainfall. Eur J Agron 33 (1): 33-42. DOI:10.1016/j.eja.2010.02.004.

Liu F, Zhang H. 2013. Novel Methods to Assess environmental, economic, and social sustainability of main agricultural regions in China. Agron Sustain Dev 16 (3): 621-633. DI: 10.1007/s13593-0120131-8.

Luo Y, Haolong F, Seydou T. 2014. Biodiversity conservation in rice paddies in China. Toward Ecol Sustain 6 (9): 6107-6124. DOI: 10.3390/ su6096107.

Lutz J, Barbara S, Nelson G. 2017. Farmer cooperation as a means for creating local food systems-potentials and challenges. Sustainability 9 (6): 925. DOI: 10.3390/su9060925.
Ministry of Agriculture of the Republic of Indonesia. 2015. Strategic Plan of the Ministry of Agriculture of the Republic of Indonesia 20152019. Jakarta, Indonesia. [Indonesian]

Morgans CL, Meijaard E, Santika T, Law E, Budiharta S, Ancrenaz M, Wilson KA. 2018. Evaluating the effectiveness of palm oil certification in delivering multiple sustainability objectives. Environ Res Lett 13: 2-11. DOI: 10.1088/1748-9326/aac6f4.

Nazam M, Sabiham S, Pramudya B, Widiatmaka, Rusastra IW. 2011. Determination of the optimum land area of rice paddy farming supports sustainable food independence in West Nusa Tenggara. J Agro Econ 29 (2): 113-145. [Indonesian]

Pitcher TJ, Lam ME, Ainsworth C, Martindale A, Nakamura K, Perry RI, Ward T. 2013. Improvements to rapfish: A rapid evaluation technique for fisheries integrating ecological and human dimensions. J Fish Biol 83: 865-889. DOI: $10.1111 / \mathrm{jfb} .12122$.

Republic of Indonesia Law Number 18 the Year 2012 about Food and Nutrition. Jakarta. [Indonesian]

Republic of Indonesia Government Regulation Number 17 the Year 2015 about Food Security and Nutrition. Jakarta. [Indonesian]

Ryan T. 2013. Sample Size Determination and Power. John Wiley and Sons, New York

Sanchez JAA, Maria PR, Juan FVM, Francisco MA. 2019. Worldwide research trends on sustainable land use in agriculture. J Land Use Pol 87. DOI: $10.1016 /$ j.landusepol.2019.104069.

Shafiqullah, R, Machito M. 2017. Current agricultural status and problems faced in Paghman district of Kabul Province, Afghanistan. Intl J Environ Rural Dev 8 (1): 183-189. DOI: 10.32115/ijerd.8.1_183.

Suciantini. 2015. Climate interaction (rainfall) to the production of food crops in Pacitan. Pros Sem Nas Masy Biodiv Indon 1 (2): 358-365. [Indonesian]

Susilowati SH, Mohammad M. 2012. Area of farmland and welfare of farmers: the existence of small-scale farmers and the urgency of agrarian reform policies. J Agric Pol Anal 10 (1): 17-30. [Indonesian]

Thanh NV, Yapwattanaphun C. 2015. Banana farmers adoption of sustainable agriculture practices in the Vietnam uplands: the case of Quang Tri Province. Agric Agric Sci Procedia 5: 67-74. DOI: 10.1016/j.aaspro.2015.08.010.

Unadi A, Suparlan. 2011. Agricultural technology support for rural agribusiness industrialization. National seminar paper on agricultural extension at agro expo activities on July 2, 2011. Center for The Development of Agricultural Mechanization, Bogor. [Indonesian]

Uphoff N, Frank BD. 2016. Making rice production more environmentally friendly. J Environ 3 (2): 1-7 DOI: 10.3390/environments3020012.

Villanoa R, Bright OA, Boris BU. 2018. Farming systems and productivity gaps: opportunities for improving smallholder performance in the forest-savannah transition zone of Ghana. J Land Use Pol 82: 220-227. DOI: 10.1016/j.landusepol.2018.12.010.

Zaharaddeen DM, Katsuyuki S, Yumi Y. 2017. Comparison of land and water improvement projects and the water management system between Japan and Nigeria. Intl J Environ Rural Dev 8 (1): 124-131. DOI: 10.32115/ijerd.8.1_124. 